\title{
The Struggle for Legitimacy: South Africa's Divided Labour Movement and International Labour Organisations, $1919-2019^{1}$
}

\author{
Duncan Money
}

Text version of my chapter that was published in Stefano Belluci and Holger Weiss (eds.), The Internationalisation of the Labour Question: Ideological Antagonism, Workers' Movements and the ILO since 1919 (Basingstoke: Palgrave Macmillan, 2020), pp. 383-408.

\section{https://doi.org/10.1007/978-3-030-28235-6 17}

\begin{abstract}
Who could be considered a legitimate representative of South Africa's working class, and even who constituted this class, was bitterly contested during the twentieth century. This chapter examines the struggles for international recognition by the rival constituents of South Africa's labour movement, which was sharply divided along racial and ideological lines. Initially, the ILO and other international labour organisations formed links with the white-dominated labour movement, which regarded itself as the legitimate representative of all workers in South Africa. This position was successfully contested by emerging black African trade unions who themselves, in the face of fierce repression, competed for financial support made available by various sections of the international labour movement.
\end{abstract}

\section{Introduction}

The origins of South Africa's labour force and trade union movement has meant that both the working class and its organisations have always had a strong international dimension. Industrialisation and urbanisation were triggered by the discovery of vast quantities of gold

\footnotetext{
${ }^{1}$ I am grateful to Danelle van Zyl-Hermann for her comments and assistance with this chapter.
} 
on the Witwatersrand in 1886 and this brought millions of people to South Africa as labour migrants from across Southern Africa and from overseas. However, Africans forced into waged work by land alienation and new colonial taxes, indentured workers recruited from South Asia, and white workers who migrated from Europe or moved from the land into new cities all had very different experiences of life and work. These experiences were strongly shaped by profound and persistent racial divisions that were enforced by an array of legislation that placed political power in the hands of South Africa's white minority and granted full political rights only to whites. Labour legislation restricted most work deemed to be skilled to whites and imposed vastly different rates of pay and rights on African, coloured, Indian and white workers.

White workers who migrated to South Africa brought with them the ideas and traditions of the labour movement from across and beyond the British Empire and, initially at least, assiduously maintained connections with trade unions across the empire. ${ }^{2}$ The trade unions established by these workers in South Africa were often, but not always, racially exclusive bodies and it was with these bodies that international labour organisations first established links. In the 1950s and 1960s, the emergence of independent African trade unions and a sharp swing to the right by much of the white labour movement, brought about a profound and enduring re-orientation of support towards African unions and against the system of apartheid that many white unions actively supported.

Apartheid was an issue that galvanised the international labour movement more than perhaps any other and opposition to apartheid became a principle that cut across the divide in the international labour movement. Importantly, international labour organisations also acted on anti-apartheid principles. South Africa was forced to withdraw from the International Labour Organisation (ILO) in March 1964 - and only re-joined in 1995 after the end of apartheid - and the ILO subsequently embarked on an anti-apartheid programme that Nelson Mandela referred to as "important elements in the common efforts of all humanity to

\footnotetext{
${ }^{2}$ Elaine Katz, A Trade Union Aristocracy: A History of White Workers in the Transvaal and the General Strike of 1913 (Johannesburg: African Studies Institute, 1976).
} 
isolate and by this means destroy the system of apartheid." ${ }^{3}$ The International Confederation of Free Trades Unions (ICFTU) also popularised boycotts and sanctions on South Africa from 1959 and provided an enormous assistance programme for newly established African trade unions in the 1970s and 1980s that one scholar concluded "no doubt is the single largest one in the history of trade unionism."

The extent and forms of international solidarity for South Africa's labour movement are well known, ${ }^{5}$ and there is an extensive literature on South Africa's labour movement. ${ }^{6}$ This chapter therefore does not provide a comprehensive overview of the relationship between international labour organisations and South Africa or their role in the anti-apartheid struggle. Instead, it focuses on the contestations among South Africa's bitterly divided labour movement for recognition by the international labour movement. These contestations, I argue, were not only about power and resources but revolved around the questions of who legitimately constituted the working class in South Africa and which organisations could therefore claim to represent this class.

International recognition bolstered the domestic position of the organisations who could secure it and, during the apartheid period, became necessary to ensure organisational survival in a repressive climate. Initially, it was the white labour movement which claimed this mantle and white trade unionists successfully presented themselves as the legitimate representatives of all workers in South Africa, and jealously guarded this position. It took several decades for the organisations of African workers to disrupt this, but. Yet contestations

\footnotetext{
${ }^{3}$ ILO, Address by Mr. Nelson Mandela at the 77th International Labour Conference, 1999, https://www.ilo.org/global/about-the-ilo/newsroom/statements-and-speeches/WCMS 215611/lang-en/index.htm. Accessed 7 February 2019.

4 Tore Linné Eriksen, Norway and National Liberation in Southern Africa (Uppsala: Nordic Africa Institute, 2000): 339.

${ }^{5}$ Roger Southall, Imperialism or Solidarity: International Labour and South African Trade Unions (Cape Town: University of Cape Town Press, 1995); Eriksen, Norway and National Liberation; Tor Sellström, Sweden and National Liberation in Southern Africa Volume II: Solidarity and Assistance 1970-1994 (Uppsala: Nordic Africa Institute, 2002); Roger Southall and Andries Bezuidenhout, "International Solidarity and Labour in South Africa", in Labour and Globalisation: Results and Prospects, ed, Ronald Munck (Liverpool: Liverpool University Press, 2004): 128-144; Håkan Thörn, Anti-Apartheid and the Emergence of a Global Civil Society (Basingstoke: Palgrave Macmillan, 2006).

${ }^{6}$ Bill Freund, "Labour Studies and Labour History in South Africa: Perspectives from the Apartheid Era and After," International Review of Social History 58 (2013): 493-519.
} 
were not only along racial lines. Political and ideological questions split both the white labour movement - parts of which occasionally formed uneasy multi-racial federations encompassing coloured and Indian workers - and the black African labour movement.

The structure of many international labour organisations generated conflict by creating a zero-sum game for recognition. International labour federations generally sought one 'national' affiliate and the annual ILO conference had one workers representative per country. Article 3 of the ILO Constitution stipulates that individual member governments should select delegates representing employers and workers in consultation with organisations "which are most representative of employers or workpeople."7 The status of 'most representative' was fiercely contested by different organisations within the South Africa labour movement who held conflicting views over who constituted the working class and even who could properly be considered a worker. South Africa's withdrawal from the ILO in 1964 removed this element of competition but this was replaced with competition for external assistance from different international labour organisations. The level of financial assistance provided by these organisations made securing recognition as a legitimate representative of South Africa's working class crucial.

Politics and labour legislation were closely entangled in this period. The apartheid regime did not recognise Africans as proper employees, legitimate inhabitants of urban areas or even as full citizens. Only whites were accorded this status. Disputes over labour legislation and were therefore also about racial citizenship and who could be legitimately considered to be a South African.

\section{White Labour and the Interwar Period}

The ILO, International Federation of Trade Unions (the Amsterdam International) and the Communist International were all established during what turned out to be the end of a tumultuous period of industrial unrest in South Africa in the early twentieth century. This mostly involved violent strikes by white workers and ended with an armed insurrection by

\footnotetext{
${ }^{7}$ ILO, ILO Constitution (1974). http://ilo.org/dyn/normlex/en/f?p=1000:62:0::NO:62:P62_LIST_ENTRIE_ID:2453907:NO. Accessed 7 February 2019.
} 
white miners in 1922 known as the Rand Revolt. ${ }^{8}$ The period that followed was one of relative quiescence, partly because the government then effectively co-opted the white labour movement through racially preferential legislation but perhaps also because the bloody repression of the Rand Revolt was a salutatory lesson to all workers. ${ }^{9}$

New legislation governing industrial relations was introduced by the government to avoid a repeat of this confrontation and the state began to play a more active role in regulating labour relations along racial lines. The 1924 Industrial Conciliation Act restricted the right to strike and established a system of centralised industrial councils for bargaining and negotiation between unions and employers to avoid conflict and institutionalise negotiations between trade unions and employers. Importantly, this act effectively institutionalised racial divisions within the working class. The state would only recognise trade unions formed by white, coloured or Indian workers, and only these unions could negotiate wages and working conditions. ${ }^{10}$ Africans were excluded from the definition of 'employee' and hence African trade unions could not be registered. Although African unions were not made illegal, their formation and effective functioning was significantly impaired. White workers therefore dominated the labour movement that existed in the interwar period and the white labour movement was regarded by the state as the legitimate representative of South Africa's working class.

White trade unions successfully presented themselves as the natural representatives of South Africa's working class for many years after 1919. This did not go uncontested in the interwar years, but initial efforts to build connections between the international labour organisations and African workers were tentative and perhaps even counterproductive, as can be seen in the attempts by Clement Kadalie to strength the international links of his union. Kadalie was the general secretary of the Industrial and Commercial Workers' Union (ICU), which had been founded in Cape Town in 1919 and then spread rapidly across Southern Africa. By 1927 it had at least 100,000 members, mostly African workers but with small

\footnotetext{
8 Jeremy Krikler, White Rising: The 1922 Insurrection and Racial Killing in South Africa (Manchester: Manchester University Press, 2005).

${ }^{9}$ Jeremy Krikler, "Lost Causes of the Rand Revolt," South African Historical Journal 63, no. 2 (2011): 325.

${ }^{10}$ David Yudelman, The Emergence of Modern South Africa: State, Capital, and the Incorporation of Organized Labour on the South African Gold Fields, 1902-1939 (London: Greenwood, 1983).
} 
numbers of coloured members. ${ }^{11}$ Kadalie was the first African trade unionist to attend an ILO conference, which he attended as an unofficial delegate from South Africa during a fivemonth visit to Europe in 1927.

White trade unionists had been unable to agree on a workers' delegate and the government had refused to nominate Kadalie as an official delegate, but he attended anyway. Kadalie's position as an unofficial delegate had been strengthened by his links with the Amsterdam International. The British Trade Union Congress (TUC) had advised Kadalie to affiliate the ICU to this international and, in January 1927, the ICU's application for membership was accepted..$^{12}$ Kadalie was also advised to affiliate the ICU with the existing trade unions in the white labour movement and he persuaded his National Council to do so, only for their application to be rejected. Kadalie rejected this, declaring "We have no intention of allowing the [white labour movement] to patronise us as inferiors. We will have full status or nothing." ${ }^{\prime 13}$ Shortly after Kadalie's return to South Africa, however, the ICU split over strategy and financial problems and subsequently disintegrated in the early 1930s. Some historians have attributed this collapse, in part, to the new unwieldy constitution, a complex, expensive bureaucracy and the 'non-political' stance that British socialists encouraged Kadalie to adopt. ${ }^{14}$

Not all sections of the white labour movement were with the ILO, however. Some unions voiced ideological opposition and refused to nominate delegates or contribute anything towards delegates' expenses because, as the Witwatersrand Tailors' Association explained, the ILO was "a purely capitalist organisation" so the union "is not prepared to have any say or part in its deliberations." ${ }^{15}$ Other white unions - including the Amalgamated

\footnotetext{
${ }^{11}$ Helen Bradford, A Taste of Freedom: The ICU in Rural South Africa, 1924-1930 (London: Yale University Press, 1987); Lucien Van der Walt, "The First Globalisation and Transnational Labour Activism in Southern Africa: White Labourism, the IWW, and the ICU, 1904-1934," African Studies 66, no. 2-3 (2007): 223-251.

12 Harold Jack Simons and Ray Simons, Colour and Class in South Africa, 1850-1950 (Harmondsworth: Penguin Books, 1969): 361.

${ }^{13}$ Ken Luckhardt and Brenda Wall, Organize... or Starve. The History of the South African Congress of Trade Unions (London: Lawrence \& Wishart, 1980): 44.

${ }^{14}$ Simons and Simons, Colour and Class in South Africa: 364-365.

${ }^{15}$ Letter from C.F. Glass to South African Association of Employee's Organizations, 16 February 1926, AH646, Cc10.4, Historical Papers Archive [hereafter HPA], University of the Witwatersrand, Johannesburg.
} 
Engineering Union and the Building Workers' Industrial Union - agreed. Even the workers' delegate at the 1925 ILO conference, H.W. Sampson, was sceptical of the organisation and reported back that 'the general feeling prevailing in the workers' group' at the ILO was "what earthly use is it?"16

Sampson's position at this conference was itself contested. On arrival, officials from the Amsterdam International on behalf of the South African Industrial Federation, a whitesonly body that had effectively collapsed after most of its affiliates formed a new short-lived federation, lodged an objection to his credentials on the grounds that it should have selected South Africa's representative. ${ }^{17}$ The South African Industrial Federation dissolved soon after but hostility from the Amsterdam International continued and South African delegates to the ILO subsequently found themselves excluded from caucuses and debates in the workers' group as they were not affiliated with the Amsterdam International. ${ }^{18}$ Sampson's report also highlighted another criticism of his presence at the ILO conference that would become more salient in the coming decades: he reported that he had been 'constantly taunted' at the conference 'that I represented the white workers only'. His reply 'that I represented the organized workers' would remain the white labour movement's argument, but he also suggested that future delegations included a representative of African workers. ${ }^{19}$

This suggestion was ignored for the next thirty years and until 1949, the whitedominated South African Trades \& Labour Council (SATLC) continued to nominate and vote on white trade unionists to send to Geneva in often closely contested elections and enjoyed a relatively co-operative relationship with the South African Government, which was keen to mollify the white labour movement. Claims from the Cape Federation of Labour Unions - a federation of mostly white trades unions based in Cape Town - that it was the most representative body of workers in South Africa, were rebuffed. ${ }^{20}$ Representation at the ILO helped white trade unionists bolster wider international ties as South African delegates who

\footnotetext{
${ }^{16}$ Report of Workers' Delegate to the International Labour Conference, 1925, AH646, Cc10.4, HPA.

${ }^{17}$ Report of Workers' Delegate to the International Labour Conference, 1925.

${ }^{18}$ Letter from A.M. Merkel to F.H.P. Creswell, Minister of Labour, 18 August 1931, AH646, Dc12.15, HPA.

${ }^{19}$ Report of Workers' Delegate to the International Labour Conference, 1925.

${ }^{20}$ Letter from Secretary, SATLC to Department of Labour, 30 January 1933, AH646, Dc12.15, HPA.
} 
travelled to Geneva often used the opportunity to visit Britain and maintain cordial ties with British trade unions, or occasionally attend more radical gatherings such as the Second AntiImperialists Congress in Frankfurt in 1929.

\section{Apartheid and Contestations in the White Labour Movement}

During the 1940s, white trade unions across Southern Africa made a concerted and partially successful effort to strength their links with international labour organisations, and to secure their position as the legitimate representatives of the working class across the region. ${ }^{21}$ This was partly motivated by radicalism and internationalism nurtured by the circumstances of war, and partly because of the emergence of assertive African trade unions which challenged white domination. In 1941, a conference of African trade unionists formed the Council of NonEuropean Trade Unions (CNETU) and one of the main demands that emerged from this conference was recognition for Africans as employees under the Industrial Conciliation Act, giving their unions equal legal status with white trade unions. ${ }^{22}$

The SATLC's outreach efforts were rewarded with an invitation to the inaugural World Federation of Trade Unions (WFTU) congress in London in 1945. This invitation came via the British TUC, who maintained close links with the SATLC and had a more cautious stance towards African unions. ${ }^{23}$ However, the SATLC delegation did not enjoy a warm reception at the WFTU. Its general secretary was defeated in his attempt be elected as the Africa representative on the WFTU Executive and his claims that the SATLC was "the most representative group in Africa" and South Africa "was the home of trade unionism as far as Africa was concerned" did not endear him to delegates from West Africa. Instead, most other delegates concluded "that [the SATLC] had come to the Conference to represent only the interests of European workers." ${ }^{24}$ Nevertheless, the SATLC did affiliate to the WFTU and their

\footnotetext{
${ }^{21}$ Duncan Money, "Race and Class in the Postwar World: The Southern African Labour Congress," International Labour and Working-Class History 94 (2018): 133-155.

${ }^{22}$ Baruch Hirson, Yours for the Union: Class and Community Struggles in South Africa (London: Zed, 1989$): 100$.

23 John Major, "The Trades Union Congress and Apartheid, 1948-1970," Journal of Southern African Studies 31, no. 3 (2005): 477-493.

${ }^{24}$ Report on the World Trade Union Congress, 6 November 1945, AH646, Dc13.7, HPA.
} 
delegates attended subsequent conferences as the representatives of South Africa, including the 1947 Pan-African Conference in Dakar in $1947 . .^{25}$

White trade unionists stressed that unions affiliated to the SATLC had African, coloured and Indian members, which was true though none were present in its leadership, and many socialist and communist trade unionists were prominent in the body. However, this supposed commitment to multi-racial trade unionism must be understood in the context of their attitude to the CNETU. Prior to the WFTU congress, the CNETU had approached the SATLC for assistance in attending the congress. White trade unionists had no intention of surrendering their position as the default representatives of South Africa, and the request was rebuffed on the grounds that recognising the CNETU - which claimed to have 119 affiliates with 158,000 members $^{26}$ - would undermine their own efforts 'to bring about one national trade union centre in the country'. Any assistance for African unions "must be under the wing" of the SATLC, rather than allowing independent representation. ${ }^{27}$ More seriously, the SATLC offered no assistance to African unions during the huge strike by African mineworkers in August 1946, which was violently suppressed. Instead, they downplayed the events and SATLC leaders sent a telegram to the WFTU reporting "Appears natives were misled by irresponsible people. Police methods controlling strike drastic but warranted." 28

The suppression of African trade unionism meant that the imminent challenge to the SATLC came not from the ranks of African unions but from right-wing, racially exclusive unions. In 1947, six whites-only unions split from the SATLC over the continued affiliation of African unions and formed the Coordinating Council of South African Trade Unions. This was followed by a further damaging split in 1950 when craft unions walked out over the same issue and formed the South African Federation of Trade Unions. ${ }^{29}$ SATLC membership collapsed from 111 unions representing 184,000 workers in 1947 to 52 unions representing

\footnotetext{
${ }^{25}$ Report of the South African Trades \& Labour Council delegate to the Pan-African Conference of the World Federation of Trade Unions, 1947, AH646, Dc13.7, HPA.

${ }^{26}$ Eddie Roux, Time Longer Than Rope (Madison: University of Wisconsin Press, 1964): 333.

${ }^{27}$ National Executive Committee, 14 August 1945, AH646, Da2.15, HPA.

28 Simons and Simons, Colour and Class in South Africa: 587.

29 Jon Lewis, Industrialisation and Trade Union Organization in South Africa, 1925-1955: The Rise and Fall of the South African Trade and Labour Council (Cambridge: Cambridge University Press, 1984): 156.
} 
82,600 workers by $1952 .{ }^{30}$ The formerly self-sufficient SATLC was forced to appeal to international allies for funding, presaging large-scale external funding of the trade union movement in the 1970 s and 1980 s. $^{31}$

These splits occurred alongside the implementation of more rigorous racial segregation at a national level, the policy of apartheid, following the victory of the National Party in the 1948 elections. Many white trade unions opposed the National Party as Afrikaner nationalists had waged a long struggle within several unions for control of the leadership during the 1930s and 1940s. ${ }^{32}$ The National Party, in turn, was not well disposed towards the largely English-speaking leadership of the white trade union movement, who had opposed Afrikaner nationalism. Now it was in government, the National Party intensified state intervention in the labour movement and ended the SATLC's default selection of the workers' ILO delegate. The new government announced that it would consult with the Western Province Federation of Labour Unions, the Coordinating Council of South African Trade Unions and the Federal Consultative Committee of the SA Railways and Harbours Staff Associations - the latter two federations representing only white workers - over the selection of the ILO delegate. Four federations were now vying for international recognition.

The SATLC was furious and stated that it was "unquestionably the most representative body of organised labour in South Africa... it is the only body that can claim to the right to be consulted." ${ }^{33}$ They lodged a lengthy objection with the Credentials Committee at the ILO conference, which would become routine over following decade, and sent a representative to Geneva to raise the objection in person. ${ }^{34}$ It claimed to be 'nationally, industrially, racially and by recognized tradition' the only representative body of workers in South Africa, and initially had the support of the CNETU in this claim. ${ }^{35}$ Predictably, the government ignored these complaints and generally selected ILO delegates from whites-only federations. The ILO's

\footnotetext{
${ }^{30}$ Luckhardt and Wall, Organize... or Starve: 83.

${ }^{31}$ Letter from Dulcie Hartwell to American Federation of Labour, 26 August 1953, AH646, Dc12.15, HPA.

32 Dan O'Meara, “Analysing Afrikaner Nationalism: The 'Christian-National' Assault on White Trade Unionism in South Africa, 1934-1948," African Affairs 77, no. 306 (1978): 45-72.

${ }^{33}$ Letter from A.G. Forsyth to Secretary of Labour, 8 February 1949, AH646, Dc12.15, HPA.

${ }^{34}$ Letter from A.G. Forsyth to Director General, ILO, 25 May 1949, AH646, Dc12.15, HPA.

${ }^{35}$ Letter from E.S. Sachs to Credentials Committee, ILO, 20 June 1951, AH646, Dc12.15, HPA.
} 
Credentials Committee, however, also sided with the South African Government and repeatedly ruled that it had legitimately appointed workers' delegates.

The state became increasingly interventionist within the labour movement as it sought to undermine the position of left-wing and multi-racial trade unions - the National Party conflated communism and multi-racialism - through more repressive legislation. The 1950 Suppression of Communism Act sharply reduced the already narrow space for leftist trade unions. The law had extremely broad parameters and allowed the government to remove any trade union official deemed to be a communist from office. Hundreds of trade unionists fell victim to this. Anti-communism was also growing in strength within the white labour movement and the SATLC followed Western trade unions and disaffiliated from the WFTU at its annual conference in 1950, though a concomitant push to affiliate with the ICFTU failed, leaving the organisation without any international affiliation. ${ }^{36}$

The government also introduced more explicitly segregationist trade union legislation. The Industrial Conciliation Act was amended in 1956 prohibiting coloured workers from holding any union position in which they had authority over white workers, banning the formation of new racially mixed unions and requiring separate branches for white and coloured in existing racially mixed unions. This was accompanied by growing hostility among white trade unions towards African, coloured and Indian workers as significant changes in the labour process during and following the Second World War prompted craft unions to rely more heavily on demarcation on the basis of race rather than skill. Job fragmentation and deskilling "brought home to white craftsmen the economic advantage of racism." 37

One consequence of this growing hostility towards African unions was the disintegration of the SATLC and the reconstitution of a more openly segregationist labour movement. Two Unity Conferences were held in 1954 between the various whites-only and white-dominated trade union federations but the intended unity was between the white labour movement as the CNETU and other African organisations were excluded. The outcome was a new federation: the South African Trade Union Council - which was subsequently, and

\footnotetext{
${ }^{36}$ Lewis, Industrialisation and Trade Union: 168.

${ }^{37}$ Eddie Webster, Cast in a Racial Mould: Labour Process and Trade Unionism in the Foundries (Johannesburg: Ravan Press, 1985): 267.
} 
confusingly, reconstituted as the Trade Union Council of South Africa (TUCSA) in $1962^{38}-$ which restricted affiliation to 'registered' trade unions, i.e. barring African trade unions. ${ }^{39}$

In response, the South African Congress of Trade Unions (SACTU) was formed in March 1955 by 14 trade unions that refused to capitulate to segregation, along with the CNETU. SACTU distinguished itself with a non-racial membership; affiliated unions had a largely African membership but also included coloured, Indian and a small number of white workers. TUCSA placed great emphasis on its status as a 'multi-racial' federation, like its predecessor organisations, and though trade unions with coloured and Indian workers remained affiliated, this was never reflected in its leadership which was composed entirely of white trade unionists. SACTU presented a powerful challenge to TUCSA's pretensions as the legitimate representative of the South African working class.

SACTU also distinguished itself with a clear political stance. The organisation helped form the Congress Alliance, a broad anti-apartheid alliance centred around the African National Congress (ANC) in 1955. This political stance was also evident in its international orientation towards the WFTU, which itself reflected the involvement of the South African Communist Party in SACTU. SACTU sought to affiliate to the WFTU shortly after its foundation links between the two bodies were clandestine and loose. SACTU never paid affiliation fees and there is no record that it ever received funding from the international body. ${ }^{40}$ Suspicion over SACTU'S links with the WFTU meant that the ICFTU remained hostile towards the organisation - an ICFTU delegation visiting South Africa in 1959 even refused an invitation to SACTU's annual congress - and the ICFTU instead maintained a loose relationship with TUCSA. ${ }^{41}$

\section{The challenge of African labour and South Africa's isolation}

\footnotetext{
${ }^{38}$ Although the South African Trade Union Council was only known as the Trade Union Council of South Africa after 1962, this article refers to the organisation as TUCSA to minimise confusion between this body and the similarly named South African Congress of Trade Unions (SACTU).

${ }^{39}$ Lewis, Industrialisation and Trade Union: 156-177.

${ }^{40}$ Southall, Imperialism or Solidarity: 102.

${ }^{41}$ Southall and Bezuidenhout, "International Solidarity": 133.
} 
International attitudes towards South Africa shifted decisively in the late 1950s and early 1960 s as the South African Government intensified repression and the white labour movement became more segregationist. In this context, SACTU began to contest the position of the four federations of registered trade unions, none of which now had African members. In 1956, SACTU submitted an objection to the South African delegation on the grounds that they had not been consulted by government but SACTU's claim to be 'the only truly representative body of South African workers' was dismissed by the ILO's Credentials Committee, which concluded that it was "a minority trade union organisation." ${ }^{42}$ This Committee reach the same conclusion in 1958. SACTU persisted for two reasons. First, so that its representatives could, in the words of SACTU vice-president Moses Madhiba, use the ILO as a platform to "expose" South Africa "for what she was." 43 Second, SACTU aimed to use the ILO to force the South African Government to consult with it over the selection of ILO delegates and thereby acknowledge the status of African trade unions as legitimate organisations.

This proved fruitless. In 1959, the South African Government appointed an ILO delegate who had been nominated by the three whites-only federations, ignoring both TUCSA and SACTU. Both objected strenuously to this. SACTU reiterated that it was the only trade union federation with a non-racial membership, while TUCSA objected on the grounds that its 50 affiliates had 158,908 members, more than all other federations combined. These objections met with mixed success. The ILO did demand that the South African Government consult with SACTU in future and cease "its discriminatory policy against this trade union."44 but also ruled that the ILO delegate - a representative of the whites-only railway workers union - "is undeniably representative of South African workers," an attitude likely influenced by the existing links between the white labour movement and trade unions in Europe. ${ }^{45}$

\footnotetext{
${ }^{42}$ Fifth Report of the Credentials Committee, 21 June 1956, AH1426, Ef5, HPA.

${ }^{43}$ Luckhardt and Wall, Organize... or Starve: 389.

${ }^{44}$ Second Report of the Credentials Committee, 16 June 1959, AH1426, Ef5, HPA.

${ }^{45}$ Seventh Report of the Credentials Committee, 18 June 1959, AH1426, Ef5, HPA.
} 
The international situation changed dramatically in 1960. The massacre of 69 demonstrators at Sharpeville in March caused outrage around the world gave an urgent impetus to the anti-apartheid movement. ${ }^{46}$ Within South Africa, state repression intensified in the aftermath. Although SACTU itself was never banned, it became impossible for African unions to organise openly or even to survive without external assistance. Hundreds of SACTU members were detained during the 1960s and the organisation was hamstrung by the detention and 'banning' - individuals who were 'banned' could be placed under house arrest, prohibited from holding office in any organisation and from speaking publicly - of organisation's leadership, including all members of the newly elected national executive in 1965. ${ }^{47}$ Most leading members went into exile - where some were subsequently seconded to the WFTU - and SACTU regrouped, first in London and Prague before establishing a headquarters in Lusaka, but it never re-established itself as a force within South Africa.

At the 1961 ILO conference, Nigeria brought a resolution condemning apartheid and calling for the expulsion of the South African delegation, which passed $163-0$, with 89 countries abstaining. SACTU supported South Africa's expulsion from the ILO and called it "the first step," to be followed by "diplomatic, economic and political sanctions on South Africa."48 SACTU also had harsh criticism for TUCSA and argued that their delegates "have no claim to speak on behalf of the African workers." ${ }^{49}$ TUCSA responded by accusing SACTU of not being representative of white, coloured and Indian workers.

These criticisms clearly stung, however, as TUCSA's constitution was amended in 1962 to allow the affiliation of African unions. A grant from the International Metal Federation financed the creation of a committee to organise African workers and by 1969 thirteen African unions had affiliated to TUCSA. ${ }^{50}$ In addition, TUCSA selected a coloured trade unionist, Edgar

\footnotetext{
${ }^{46}$ Tom Lodge, Sharpeville: An Apartheid Massacre and its Consequences (Oxford: Oxford University Press, 2011).

47 Jabulani Sithole and Sifiso Ndlovu, "The Revival of the Labour Movement, 1970-80," in The Road to Democracy in South Africa Volume I, 1960-1970, ed, South African Democracy Education Trust (Cape Town: Zebra Press, 2004): 211.

${ }^{48}$ Luckhardt and Wall, Organize... or Starve: 392.

${ }^{49}$ Memorandum Submitted by the South African Congress of Trade Unions, 1961, AH1426, Ef5, HPA.

${ }^{50}$ Merle Lipton, Capitalism and Apartheid: South Africa, 1910-1986 (Aldershot: Wildwood House, 1986$): 201$.
} 
Deane, as a delegate at the ILO conference and an observer at the ICFTU conference in 1962. However, this may have backfired as Deane gave a speech at the ILO opposing any boycott of South Africa and affirming "that domestic matters affecting the workers of South Africa can best be dealt with by the South African workers themselves." 51

South Africa's position at the ILO had become untenable, and the South African Government was unwilling to defend it. At the 1963 ILO conference, South Africa's presence almost caused a constitutional crisis in the organisation as delegates tried to prevent the South African delegation from addressing the conference, and many walked out when they did. South Africa was banned from participating in most of the conference's committees and subsequently, in March 1964, opted to withdraw rather than endure than same experience. ${ }^{52}$ South Africa's departure allowed the ILO to abandon diplomatic etiquette and embrace the anti-apartheid positions of an increasing number of its member states to make uncompromising criticisms of apartheid. In 1964 the ILO unanimously adopted a policy to work towards eliminating apartheid and thereafter orientated towards the liberation movement. ${ }^{53}$

Excluding South Africa from the ILO was part of wider efforts to isolate the country and calling for a boycott of South Africa became one of the key strategies of the anti-apartheid movement. The ICFTU played an important role in popularising this strategy by initiating an international consumer boycott of South African goods in 1959 and subsequently requested that its affiliates pressure their national governments to introduce sanctions on South Africa. This was a surprising move in some ways as the ICFTU was then close to TUCSA, which opposed boycotts, and was hostile towards SACTU, which supported them.

The ICFTU's hostility towards SACTU can be seen in the decision to assist with the formation of a rival organisation of African trade unions in 1959: the Federation of Free African Trade Unions of South Africa (FOFATUSA). FOFATUSA affiliated with the ICFTU and

\footnotetext{
${ }^{51}$ E.A. Deane's Address to the $46^{\text {th }}$ Session of the International Labour Conference, 1962, AH1426, Ef5, HPA.

52 ILO, The Role of the ILO During and Ending Apartheid, 2013. https://www.ilo.org/wcmsp5/groups/public/--africa/documents/meetingdocument/wcms 214906.pdf. Accessed 7 February 2019.

53 ILO, Special Report of the Director-General on the Application of the Declaration concerning the Policy of "Apartheid " of the Republic of South Africa, 1965, https://www.ilo.org/public/libdoc/ilo/P/09832/09832(1965-1).pdf. Accessed 8 February 2019.
} 
was careful to stress its anti-communist credentials to its international sponsor. Its delegate at the 1962 ICFTU Congress, Lucy Mvubelo, warned about the dangers of "a foreign undemocratic society, the communist bloc' hoodwinking 'innocent and true African trade unionists." ${ }^{54}$ SACTU responded with a successful international campaign to delegitimise FOFATUSA and the ICFTU as organisations who were dividing the black working class. ${ }^{55}$ FOFATUSA, dissolved in 1966, its affiliated unions joined TUCSA, was described by the ICFTU as "the most representative trade union body in South Africa," and with whom the ICFTU "maintained cordial relations." 56

The ICFTU initially decided to back the boycott because to appeal to its affiliates elsewhere in Africa, some of who strongly supported the boycott, as there was a real danger in the late 1950s that African trade unions would disaffiliate en masse from the ICFTU to form an African federation. ${ }^{57}$ These wider strategic concerns, perhaps inadvertently, caused the ICFTU to orientate away from the white labour movement, though lingering imperial ties between this movement and trade unions in Britain were also dissipating in this period. TUCSA applied to affiliate to the ICFTU in $1962,{ }^{58}$ but subsequently reversed this decision over the ICFTU's support from the boycott, which was strongly opposed by the white labour movement. As one white trade unionist fumed, "The ICFTU seems to think that all workers in South Africa are Black. It forgets that there are thousands of European trade unionists and among them many men as good as any in the ranks of the ICFTU." 59

Opinion in the international labour movement had, however, shifted decisively during the 1960s, and white trade unions were marginalised. This marginalisation was confirmed in 1969 when TUCSA expelled its African affiliates and once again restricted membership to registered unions, following the disaffiliation of fifteen white-dominated craft union over

\footnotetext{
${ }^{54}$ Address by Miss Lucy Mvubelo, 1962, AH1426, Ef1, Historical Papers Archive, University of the Witwatersrand, Johannesburg.

55 Southall and Bezuidenhout, "International Solidarity”: 134.

${ }^{56}$ ICFTU, 24 February 1966, Press and Radio Service.

57 Simon Stevens, Boycotts and Sanctions against South Africa: An International History, 1946-1970, PhD diss., Columbia University, 2016: 150-174.

58 TUCSA Application for Affiliation, 22 October 1962, AH1426, Ef1, HPA.

59 “Rebuff for Boycott," Rand Daily Mail, 13 January 1960.
} 
continued affiliation of African unions. ${ }^{60}$ Consequently, when a TUCSA delegation visiting Europe in 1970 attempted to meet with the ICFTU, as they had done in previous years, they were firmly rebuffed. ${ }^{61}$ Previously, TUCSA had sent a delegation to Europe each year to attend the ILO as observers and to meet with various other European trade unions as a way of bolstering their position as representatives of workers in South Africa. This now became considerably less convincing.

\section{Revival of the labour movement}

In January 1973, wildcat strikes erupted in Durban - one of South Africa's main industrial regions - over persistently low wages and rising unemployment and involved anywhere between 60,000 and 100,000 black workers. Stoppages spread across manufacturing, heavy industry and municipal services, and demonstrated the effectiveness of co-ordinated action by black workers. ${ }^{62}$ These strikes were followed up an upsurge in anti-apartheid protests with the Soweto Uprising in 1976 and the eruption of these protests precipitated the emergence of new independent African trade unions and a new generation of black trade unionists. ${ }^{63}$

Some sections of the international labour movement quickly appreciated the significance of these developments. The British TUC sent a delegation to South Africa in October 1973 and subsequently proposed a joint funding programme for the new trade union movement in conjunction with the ICFTU. The ICFTU readily agreed and in 1974 formed the Co-ordinating Committee for South Africa to direct assistance from its affiliates to the emerging trade unions. Financial assistance enabled these new unions to hire full-time organisers, cover legal costs, run education programmes, rent offices, and essentially to establish viable organisations. According to Roger Southall, "it can be unambiguously stated that such was the extent of their initial dependence upon this funding, that the emerging

\footnotetext{
${ }^{60}$ Lipton, Capitalism and Apartheid: 200.

${ }^{61}$ Letter from General Secretary, ICFTU to J.A. Grobbelaar, 27 April 1970, AH1426, Ef5, HPA.

${ }^{62}$ Steven Friedman, Building Tomorrow Today: African Workers in Trade Unions, 1970-1984 (Johannesburg: Ravan Press, 1987).

${ }^{63}$ Sakhela Buhlungu, "Rebels without a Cause of Their Own? The Contradictory Location of White Officials in Black Unions in South Africa, 1973-94," Current Sociology 54, no. 3 (2006): 442.
} 
unions could scarcely have achieved the extent of their organisational reach without it." ${ }^{\prime 64}$ SACTU, in contrast, remained sceptical and distant from these new formations, believing that independent trade unions could not function effectively within South Africa.

Right-wing white trade unions were furious at the ICFTU's intervention. The whitesonly South African Confederation of Labour opposed even the existence of African unions and demanded that the government block financial aid to African trade unions. ${ }^{65}$ By this time, there was no question that any funding would go to the British TUC's former allies in the white labour movement. This movement remained substantial though and in 1970 there were around 390,000 white trade union members who were overwhelmingly organised in whitesonly unions. ${ }^{66}$ Most white trade unions, however, shunned international ties, or were themselves shunned when they appeared at the ILO.

However, SACTU also didn't receive any of this newly available financial assistance. The justification was that SACTU had little or no presence within South Africa, but existing mutual hostility between the ICFTU and SACTU also played a role. SACTU leaders concluded this external funding was being used to encourage new African unions to remain apolitical and restrict their demands to wages and working conditions and its general secretary Mark Shope accused the British TUC of safeguarding British investments in the South African economy and 'trying to torpedo the whole anti-apartheid programme' with its funding programme. ${ }^{67}$

SACTU did achieve some successes with international recognition, but this was mostly due to its overlapping membership of its leadership with the exiled ANC and South African Communist Party. ${ }^{68}$ SACTU representatives had greater success meeting with national governments in Western Europe than trade unions in the 1970s, as the latter accorded them

\footnotetext{
${ }^{64}$ Southall, Imperialism or Solidarity: 335.

${ }^{65}$ Muriel Horrell, Dudley Horner and Jane Hudson, A Survey of Race Relations in South Africa: 1974 (Johannesburg: South African Institute of Race Relations, 1975): 318.

${ }^{66}$ Muriel Horrell, A Survey of Race Relations in South Africa: 1970 (Johannesburg: South African Institute of Race Relations, 1971): 126.

${ }^{67}$ Sithole and Ndlovu, "The Revival of the Labour Movement": 211.

${ }^{68}$ Stephen Ellis and Tsepo Sechaba, Comrades Against Apartheid: The ANC and the South African Communist Party in Exile (London: James Currey, 1992): 6.
} 
low priority on the understanding that SACTU had ceased to exist as a trade union federation. ${ }^{69}$ One of SACTU's greatest successes in claiming the status of the representative of South Africa's working-class came in 1975 when its new general secretary, John Gaetsewe, addressed the ILO's annual conference. ${ }^{70}$ Gaetsewe, however, did so in his capacity as an ANC member, not as SACTU's general secretary.

Developments within South Africa soon eclipsed SACTU's successes in the international arena. In 1979, a new federation was formed, the Federation of South African Trade Unions (FOSATU), which was strongly influenced by the ideas of 'workerism' that stressed the importance of industrial unions organised independently of political parties. Many FOSATU activists concluded that SACTU had failed because it had been subordinated to a political agenda. ${ }^{71}$ This was followed in 1981 by the creation of the black consciousness Council of Unions of South Africa (CUSA). Both FOSATU and CUSA received funding from the ICFTU, though only CUSA, the smaller body, affiliated to the ICFTU. FOSATU had a 'policy to strive for self-sufficiency' but made 'very little progress' in the first years of its existence and remained almost totally reliant on the ICFTU. ${ }^{72}$ In 1982, for instance, fees from affiliated unions totalled only R15,253, while funding from the ICFTU totalled R341,500.73 FOSATU avoided specific alignment in the international labour movement due to the dominant political current of 'workerism'.

Black trade union membership surged during the 1980s from just over 800,000 in 1980 to over $2.7 \mathrm{~m}$ by $1991 ; ;^{74}$ and South Africa was convulsed by a massive strike wave as the number of working days lost to strikes rose from 67,099 in 1979 to a peak of $5,825,000$ in

\footnotetext{
${ }^{69}$ Sellström, Sweden and National Liberation in Southern Africa: 451-452.

${ }^{70}$ Memorandum to be Submitted by the South African Congress of Trade Unions to the $60^{\text {th }}$ Session of the International Labour Organisation, 1975, AH1999, C6.12.2, HPA.

${ }^{71}$ Sian Byrne, Nicole Ulrich and Lucien van der Walt, "Red, Black and Gold: FOSATU, South African 'Workerism', 'Syndicalism' and the Nation," in The Unresolved National Question in South Africa: Left Thinking Under Apartheid, eds. Edward Webster and Karin Pampillas (Johannesburg: Wits University Press, 2017): 258.

72 FOSATU Budget Proposals, 1983, AH1999, C5.2, HPA.

${ }^{73}$ Income and Expenditure Statement for the Year Ended 31 December 1982, 1983, AH1999, C5.2, HPA.

74 Ian Macun and Andrew Frost, "Living Like There's No Tomorrow: Trade Union Growth in South Africa, 19791991," Social Dynamics 20, no. 2 (1997): 76.
} 
1987. ${ }^{75}$ Industrial unions affiliated with FOSATU - especially among metalworkers experienced rapid growth and FOSATU's membership rose from 45,000 members in 1979 to around 140,000 members by $1985 .{ }^{76}$ Although it had a predominately black African membership, FOSATU's ranks also contained sizeable numbers of coloured and Indian workers and a few white workers as the organisation was based on the principles of nonracialism that entailed the rejection of apartheid racial categorisations. The principle of a multi-racial membership was assisted when the Industrial Conciliation Act was repealed in 1981 and replaced by legislation that granted trade union rights to all workers in South Africa. ${ }^{77}$

The rising tide lifted all boats. TUCSA had once again allowed African trade unions to affiliate in 1974 and experienced significant membership growth. By 1983, it was the largest trade union federation by far with 57 affiliated unions and almost 500,000 members. Its plea to the ILO that it was an organisation 'within which all workers in South Africa can stand united, irrespective of any differences arising from colour, race, national origin, or any other division irrelevant to a workers' status as a worker' was ignored, however. ${ }^{78}$ TUCSA's $^{\prime}$ conservatism was ill-suited to a period of industrial militancy and political polarisation and most of its largest affiliated unions soon disaffiliated or defected to FOSATU.

In November 1985, FOSATU merged with the newly established National Union of Mineworkers and other independent unions to form an even larger, non-racial federation: the Congress of South African Trade Unions (COSATU). COSATU was formed in a period when the anti-apartheid struggle within South Africa was perhaps at its most intense and it had an explicit political orientation, in contrast to FOSATU. COSATU's formation effectively ended debates about which organisation was representative of the working class in South Africa as its size, influence and rapid growth soon far outstripped would-be rivals. At its formation, COSATU had 33 affiliates with 462,359 members and by 1991 its affiliates had a combined

\footnotetext{
${ }^{75}$ Wessel Visser, "A Racially Divided Class: Strikes in South Africa, 1973-2004," in Strikes Around the World, 1968-2005: Case Studies of 15 Countries, eds. Sjaak van der Velden et al. (Amsterdam: Aksant, 2007): 50.

${ }^{76}$ Jeremy Baskin, Striking Back: A History of COSATU (Johannesburg: Ravan Press, 1991): 49.

77 Visser, "A Racially Divided Class": 47.

${ }^{78}$ Letter from J.A. Grobbelaar to Director General, ILO, 29 November 1983, AH1426, Ef5, HPA.
} 
membership of $1,258,853 .^{79}$ In December 1986, TUCSA dissolved, its membership having fallen to 32 affiliates with only around 170,000 members, ${ }^{80}$ a development which the ILO concluded marked the end of White domination over a broad sector of the trade union field'. ${ }^{81}$ SACTU admitted defeat soon afterwards. In March 1990 SACTU and COSATU met in Lusaka where it was agreed that SACTU would be dissolved, and COSATU would take its place in the Congress Alliance.

The strength of COSATU's position altered the relationship with external organisations. The ICFTU were faced with the awkward position that COSATU refused to receive any funding from the ICFTU because, according to ICFTU Secretary General Johnny Vanderveken, "that there are 'good' and 'bad' organisations within ICFTU, and money from "bad' organisations... cannot be accepted by COSATU." ${ }^{82}$ It was unacceptable to the ICFTU that an outsider organisation would dictate which affiliates were politically palatable, but COSATU were in a position to do so. The balance of power between international and South African organisations had been altered. International labour organisations continued to provide training and technical assistance for COSATU, ${ }^{83}$ but this was of a different character than the financial assistance that had enabled new black trade unions to survive during the 1970s.

\section{Conclusion}

The position described in this chapter of rival trade unions and federations vying for international affiliation and recognition as the legitimate representation of South Africa's working class has largely been reversed since the end of apartheid. While many national labour movements, especially in the developed world, have atrophied, South Africa's trade

\footnotetext{
79 Macun and Frost, "Living Like There's No Tomorrow": 77.

${ }^{80}$ National Executive Committee, 2 December 1986, AH 1426, Acl.1.9, HPA.

81 ILO, Special Report of the Director-General on the Application of the Declaration Concerning the Policy of Apartheid in South Africa, 1987: 8, https://www.ilo.org/public/libdoc/ilo/P/09832/09832(1987-23).pdf. Accessed 5 March 2019.

82 Eriksen, Norway and National Liberation: 343.

83 ILO, The Role of the ILO During and Ending Apartheid, 2013.
} 
union movement remains large, influential and with the prestige of having played a central role in defeating apartheid. International federations now court COSATU as an affiliate and COSATU has become entangled in rivalry between the International Trade Union Confederation (ITUC) and the WFTU.

COSATU affiliated to the ICFTU in 1997 and the ICFTU held its $17^{\text {th }}$ Congress in South Africa to cement these ties, but COSATU occupied an uneasy position in the federation. COSATU, on paper at least, was more radical than most other ICFTU affiliates and its explicit anti-capitalist and anti-imperialist politics were ideologically much closer to the WFTU. Four trade unions affiliated with COSATU - including its largest affiliate, the National Union of Mineworkers - affiliated directly to the WFTU, and pressured COSATU to do the same and to disaffiliate from the ITUC. Meanwhile, the WFTU openly courted COSATU's affiliation and held it's $17^{\text {th }}$ Congress in South Africa in 2016. This bore success and in 2018 COSATU affiliated to the WFTU but, at present, also remains an ITUC affiliate. ${ }^{84}$

Competition remains an important part of the relationship between South Africa's labour movement and international labour organisations. The character of this competition has changed significantly since the 1980 s though. Bitter debates over who constituted the working class in South Africa and whether white trade unionists were the legitimate representatives of this class have been resolved, and the remaining sections of the white labour movement do not make any claims to represent the wider working class. Until recently, COSATU's position as the dominant force in the country's labour movement and most representative organisation of the working class has not been seriously contested since its formation. The South African workers' delegate at the annual ILO conference, for instance, is always selected from COSATU's leadership. This may change in the future. The decision by the National Union of Metalworkers of South Africa, the country's largest union, to form the South African Federation of Trade Unions in 2017 after it split from COSATU could herald a new period of struggle around who is the legitimate representative of labour in South Africa.

\footnotetext{
${ }^{84}$ WFTU, We Welcome COSATU Home, 2018, http://www.wftucentral.org/we-welcome-cosatu-home/. Accessed 5 February 2019.
} 


\section{Bibliography}

\section{Archival Sources}

Historical Papers Archive, University of the Witwatersrand, Johannesburg

AH646, Trade Union Council of South Africa, 1915-1964.

AH1426, Trade Union Council of South Africa, 1965-1985.

AH1999, Federation of South African Trade Unions, 1939-1987.

\section{Published Sources}

ICFTU, 24 February 1966, Press and Radio Service.

ILO, Special Report of the Director-General on the Application of the Declaration concerning the Policy of "Apartheid " of the Republic of South Africa, 1965, https://www.ilo.org/public/libdoc/ilo/P/09832/09832(1965-1).pdf. Accessed 8 February 2019.

ILO, ILO Constitution

http://ilo.org/dyn/normlex/en/f?p=1000:62:0::NO:62:P62 LIST ENTRIE ID:2453907:NO.

Accessed 7 February 2019.

ILO, Special Report of the Director-General on the Application of the Declaration Concerning the Policy of Apartheid in South Africa, 1987, https://www.ilo.org/public/libdoc/ilo/P/09832/09832(1987-23).pdf. Accessed 5 March 2019. ILO, Address by Mr. Nelson Mandela at the 77th International Labour Conference, 1999, https://www.ilo.org/global/about-the-ilo/newsroom/statements-andspeeches/WCMS 215611/lang--en/index.htm. Accessed 7 February 2019.

ILO, The Role of the ILO During and Ending Apartheid, 2013. https://www.ilo.org/wcmsp5/groups/public/--africa/documents/meetingdocument/wcms 214906.pdf. Accessed 7 February 2019. 
Rand Daily Mail

WFTU, We Welcome COSATU Home, 2018, http://www.wftucentral.org/we-welcomecosatu-home/. Accessed 5 February 2019.

\section{Research literature}

Baskin, Jeremy, Striking Back: A History of COSATU (Johannesburg: Ravan Press, 1991).

Bradford, Helen, A Taste of Freedom: The ICU in Rural South Africa, 1924-1930 (London: Yale University Press, 1987).

Buhlungu, Sakhela, "Rebels without a Cause of Their Own? The Contradictory Location of White Officials in Black Unions in South Africa, 1973-94," Current Sociology 54, no. 3 (2006): 427-451.

Byrne, Sian, Nicole Ulrich and Lucien van der Walt, "Red, Black and Gold: FOSATU, South African 'Workerism', 'Syndicalism' and the Nation," in The Unresolved National Question in South Africa: Left Thinking Under Apartheid, eds. Edward Webster and Karin Pampillas (Johannesburg: Wits University Press, 2017): 245-273.

Ellis, Stephen and Tsepo Sechaba, Comrades Against Apartheid: The ANC and the South African Communist Party in Exile (London: James Currey, 1992).

Eriksen, Tore Linné, Norway and National Liberation in Southern Africa (Uppsala: Nordic Africa Institute, 2000).

Friedman, Steven, Building Tomorrow Today: African Workers in Trade Unions, 1970-1984 (Johannesburg: Ravan Press, 1987).

Freund, Bill. 2013. "Labour Studies and Labour History in South Africa: Perspectives from the Apartheid Era and After," International Review of Social History 58 (2013): 493-519.

Hirson, Baruch, Yours for the Union: Class and Community Struggles in South Africa (London: Zed, 1989).

Horrell, Muriel, A Survey of Race Relations in South Africa: 1970 (Johannesburg: South African Institute of Race Relations, 1971). 
Horrell, Muriel, Dudley Horner and Jane Hudson, A Survey of Race Relations in South Africa: 1974 (Johannesburg: South African Institute of Race Relations, 1975).

Katz, Elaine, A Trade Union Aristocracy: A History of White Workers in the Transvaal and the General Strike of 1913 (Johannesburg: African Studies Institute, 1976).

Krikler, Jeremy, White Rising: The 1922 Insurrection and Racial Killing in South Africa (Manchester: Manchester University Press, 2005).

Krikler, Jeremy, "Lost Causes of the Rand Revolt," South African Historical Journal 63, no. 2 (2011): 318-338.

Lewis, Jon, Industrialisation and Trade Union Organization in South Africa, 1925-1955: The Rise and Fall of the South African Trade and Labour Council (Cambridge: Cambridge University Press, 1984).

Lipton, Merle, Capitalism and Apartheid: South Africa, 1910-1986 (Aldershot: Wildwood House, 1986).

Lodge, Tom, Sharpeville: An Apartheid Massacre and its Consequences (Oxford: Oxford University Press, 2011).

Luckhardt, Ken and Brenda Wall, Organize... or Starve. The History of the South African Congress of Trade Unions (London: Lawrence \& Wishart, 1980).

Macun, lan and Andrew Frost, "Living Like There's No Tomorrow: Trade Union Growth in South Africa, 1979-1991," Social Dynamics 20, no. 2 (1997): 67-90.

Major, John, "The Trades Union Congress and Apartheid, 1948-1970," Journal of Southern African Studies 31, no. 3 (2005): 477-493.

Money, Duncan, "Race and Class in the Postwar World: The Southern African Labour Congress," International Labour and Working-Class History 94 (2018): 133-155.

O'Meara, Dan, “Analysing Afrikaner Nationalism: The 'Christian-National' Assault on White Trade Unionism in South Africa, 1934-1948," African Affairs 77, no. 306 (1978): 45-72.

Roux, Eddie, Time Longer Than Rope (Madison: University of Wisconsin Press, 1964). 
Sellström, Tor, Sweden and National Liberation in Southern Africa Volume II: Solidarity and Assistance 1970-1994 (Uppsala: Nordic Africa Institute, 2002).

Simons, Harold Jack and Ray Simons, Colour and Class in South Africa, 1850-1950 (Harmondsworth: Penguin Books, 1969).

Sithole, Jabulani and Sifiso Ndlovu, "The Revival of the Labour Movement, 1970-80," in The Road to Democracy in South Africa Volume I, 1960-1970, ed, South African Democracy Education Trust (Cape Town: Zebra Press, 2004): 187-202.

Southall, Roger, Imperialism or Solidarity: International Labour and South African Trade Unions (Cape Town: University of Cape Town Press, 1995).

Southall, Roger and Andries Bezuidenhout, "International Solidarity and Labour in South Africa", in Labour and Globalisation: Results and Prospects, ed, Ronald Munck (Liverpool: Liverpool University Press, 2004): 128-144.

Stevens, Simon, Boycotts and Sanctions against South Africa: An International History, 19461970, PhD diss., Columbia University, 2016.

Thörn, Håkan, Anti-Apartheid and the Emergence of a Global Civil Society (Basingstoke: Palgrave Macmillan, 2006).

Van der Walt, Lucien, "The First Globalisation and Transnational Labour Activism in Southern Africa: White Labourism, the IWW, and the ICU, 1904-1934," African Studies 66, no. 2-3 (2007): 223-251.

Visser, Wessel, “A Racially Divided Class: Strikes in South Africa, 1973-2004," in Strikes Around the World, 1968-2005: Case Studies of 15 Countries, eds. Sjaak van der Velden et al. (Amsterdam: Aksant, 2007): 40-60.

Webster, Eddie, Cast in a Racial Mould: Labour Process and Trade Unionism in the Foundries (Johannesburg: Ravan Press, 1985).

Yudelman, David, The Emergence of Modern South Africa: State, Capital, and the Incorporation of Organized Labour on the South African Gold Fields, 1902-1939 (London: Greenwood, 1983). 